\title{
Futebol, gênero e homossociabilidade nas redes sociais: a masculinidade no circuito comunicacional do WhatsApp
}

Soccer, gender and homo-sociability on social media: masculinity on a WhatsApp communication circuit

Fútbol, Género y homossociabilidad en las redes sociales: masculinidad en el circuito comunicacional WhatsApp

DOI: https://doi.org/10.1590/1809-5844202019

\section{Adriana Andrade Braga ${ }^{1}$}

https://orcid.org/0000-0002-0307-3470

\section{Alexandre Augusto Freire Carauta ${ }^{1}$}

https://orcid.org/0000-0002-3607-8710

${ }_{1}^{1}$ (Pontifícia Universidade Católica do Rio de Janeiro, Departamento de Comunicação, Programa de PósGraduação em Comunicação Social. Rio de Janeiro - RJ, Brasil).

\section{Resumo}

O futebol é um elemento fundamental na cultura e identidade nacional brasileiras. Marcado por um viés de identidade masculina, o futebol no Brasil relaciona-se a valores como honra, sexualidade e dignidade. A incorporação dos processos digitais na vida cotidiana tem reconfigurado a comunicação tematizada pelo futebol entre torcedores no âmbito das redes sociais. Elementos identificados em estudos anteriores na sociabilidade entre torcedores, como a jocosidade e a afirmação de masculinidade dominantes, atualizam-se nas plataformas digitais. Partindo de uma abordagem netnográfica, esta pesquisa buscou identificar arranjos identitários e interacionais no circuito comunicacional de um grupo de "peladeiros" no WhatsApp. Os resultados apontam para padrões de reiteração da masculinidade hegemônica, em termos de "homossociabilidade masculina”, "jocosidade de gênero" e "sátira política".

Palavras-chave: Futebol. Gênero. Identidade. Redes sociais. WhatsApp. Homossociabilidade masculina.

\section{Abstract}

Soccer is a fundamental issue on Brazilian culture and national identity. Defined by a bias of male identity, soccer in Brazil is related to values as honor, sexuality and dignity. The inclusion of social media in everyday life has changed the way ordinary fans talk about soccer. Elements of ordinary soccer sociability pointed out in other studies, such as playfulness and the affirmation of dominant 
male stereotypes are renewed on social media. Departing from a nethnographic research, this study identified a number of interactional arrangements on the communication circuit of a group of informal soccer players on WhatsApp. The results point out to patterns of re-affirmation of masculine hegemony, in terms of "male homo-sociability", "gender playfulness" and "political satire".

Keywords: Soccer. Gender. Identity. Social Media. WhatsApp. Male Homo-sociability.

\section{Resumen}

Fútbol es un elemento fundamental en la cultura y la identidad nacional brasileñas. Marcado por un viés de identidad masculina, fútbol en Brasil se relaciona con valores como honor, sexualidad y dignidad. La incorporación de tecnologías digitales en la vida cotidiana han reconfigurado la comunicación entre hinchas de fútbol en las redes sociales. Elementos identificados en otros estudios cerca de la sociabilidad entre hinchas, como la jocosidad y la afirmación de la masculinidad hegemónica son actualizados en las plataformas digitales. Partiendo de un abordaje netnográfica, esta investigación identificó padrones de identidad y interacción en el circuito comunicacional de un grupo de "peladeros" (jugadores informales) de fútbol en WhatsApp. Los resultados evidencian la reiteración de la masculinidad hegemónica, en terminos de la "homossociabilidad masculina", “jocosidad de género” y “sátira política”.

Palabras-clave: Fútbol. Género. Identidad. Redes sociales. WhatsApp. Homossociabilidad masculina.

\section{Introdução}

“O Vasco é tricampeão em levar 4 a 0. Já pode pedir música no Fantástico1”, provoca um rubro-negro os amigos vascaínos, depois de o time ser goleado pelo Cruzeiro e praticamente ser eliminado da Libertadores 2018. “Isso é real ou é cruzeiro”, acrescenta outro torcedor rival. "Não estou nem aí”, defende-se um vascaíno. O debate lúdico poderia ter transcorrido em um bar, praça, churrasco pós-pelada ou no intervalo para o café no escritório, mas deu-se em um grupo de WhatsApp composto por “peladeiros”, que será detalhado adiante. Nesses ambientes online, provocações tradicionais da cultura do futebol atualizam-se sob formatos de texto, áudio e vídeo, veiculados pelos circuitos comunicacionais digitais. Peculiar às relações sociais tematizadas pelo futebol, as práticas de provocações amistosas entre torcedores adversários estão presentes nos diversos ambientes digitais.

Este artigo analisa, a partir de uma perspectiva netnográfica, a interação social entre os participantes de um grupo de jogadores de futebol amador a partir dos registros de suas mensagens em um grupo de WhatsApp. Assim, após esta introdução, discutimos a interação social mediada por smartphone, a relação entre futebol e masculinidade e aspectos da técnica netnográfica aplicada. A análise explora uma caracterização geral do fenômeno seguida de uma leitura da interação através dos textos e imagens veiculados.

1 Alusão jocosa ao quadro do programa dominical Fantástico da TV Globo, no qual um jogador profissional que marca três gols, ou mais, nos jogos da semana, pode pedir uma música, que é reproduzida parcialmente durante o programa. 
Esta investigação se apoia no princípio da ecologia das mídias (STRATE; BRAGA; LEVINSON, 2019), segundo o qual os ambientes comunicacionais proporcionados pelas tecnologias reconfiguram os espectros simbólico-culturais, as identidades e subjetividades, a linguagem (LOGAN, 2002); alteram a forma como percebemos o mundo, como pensamos, interagimos, nos expressamos (BRAGA, 2008). Perspectiva sintetizada no célebre aforismo “o meio é a mensagem” (MCLUHAN, 1964), de que novos suportes tecnológicos condicionam novos usos, novos hábitos, derivados de novos ditames socioculturais, intelectuais e políticos.

Neste sentido, uma inovação tecnológica não é neutra, pois promove custos e benefícios assimetricamente distribuídos na sociedade, com os quais seus integrantes têm de negociar (POSTMAN, 1994). Impõe novos repertórios simbólicos, léxicos, espaciais, interacionais, que, aplicados às dimensões do futebol midiatizado, alteram seus modos de experiência e interação, - neste caso, relacionadas ao mundo do esporte.

O futebol é um elemento fundamental na cultura e constituição da identidade nacional brasileiras. Em termos da identidade masculina, esse traço identitário ganha proporções ainda maiores, relacionando-se a valores como honra, sexualidade, moral e dignidade. Impulsionada pelas Tecnologias da Informação e Comunicação, a incorporação dos processos digitais tem reconfigurado a comunicação tematizada pelo futebol estabelecida por torcedores no âmbito das redes sociais online. Elementos identificados em estudos anteriores (RIAL, 2003, DAMO, 2007, GASTALDO, 2006) na sociabilidade entre torcedores, como a jocosidade e a afirmação de masculinidade predominantes, atualizamse nas plataformas digitais. Partindo de uma abordagem netnográfica, este estudo buscou identificar arranjos identitários e interacionais no circuito comunicacional estabelecido entre um grupo de "peladeiros” no WhatsApp, composto por moradores da Zona Sul do Rio de Janeiro, durante o ano de 2018.

O estudo identificou padrões comunicacionais específicos em relação à masculinidade culturalmente idealizada (GASTALDO, 2006, 2010, DAMO, 2003, 2007), somando-se aos esforços em compreender como os circuitos comunicacionais, com a simplificação e multiplicação de interfaces para conteúdos digitais, tornam-se ambientes significativos “para apresentações do self, onde são veiculadas representações de identidade, individualidade e pertencimento, em uma dinâmica análoga ao que Goffman (1998) denomina "gerenciamento da impressão” (BRAGA, 2008).

\section{Smartphones e o futebol}

Desde o desenvolvimento da chamada Web 2.0, no início dos anos 2000, uma série de redes sociais e aplicativos se popularizaram. Atualmente, no Brasil e em muitos outros países, um dos aplicativos de rede social mais populares é o WhatsApp, devido a suas características únicas de formação de grupos e registro de conta a partir do número de telefone, tendo o smartphone como interface. O trecho a seguir expõe essas características com clareza: 
Embora o compartilhamento gratuito de informações pela Internet seja comum a muitas redes sociais e outros serviços de mensagens públicas, como o Twitter, existe, a natureza privada da rede WhatsApp o torna único.

Uma diferença semelhante entre o WhatsApp e outras redes sociais é que a associação é criada e atualizada diretamente através dos smartphones das pessoas. O registro não é feito exclusivamente através do número de telefone de uma pessoa, mas o smartphone é a interface principal para enviar e receber mensagens. Terceiro, os grupos de conversas interpessoais do WhatsApp são o único meio de comunicação da rede e são formados pela adição de números de telefone de pessoas a esse grupo. Por outro lado, outras redes sociais são baseadas na associação de usuários e se concentram principalmente em mensagens públicas nas quais essas mensagens são enviadas a todos os usuários conectados (ou seja, essas mensagens são chamadas de Postagens no Facebook e Tweets no Twitter), e não por meio de grupos privados (ROSENFELD; SINA; SARNE, 2018) ${ }^{2}$.

A onipresença de dispositivos conectados à Internet no dia a dia do mundo do futebol, a exemplo dos demais ambientes sociais contemporâneos, é notável. A fatídica goleada da Alemanha sobre o Brasil na semifinal da Copa de 2014, assistida por 428 milhões de telespectadores/as, segundo a Fifa, repercutiu também no Facebook, que bateu o recorde de três bilhões de publicações ${ }^{3}$ durante o Mundial. As mensagens disseminavam-se também por outros aplicativos largamente acessados por smartphones, como Twitter, WhatsApp e Instagram. O protagonismo midiático do jogo na televisão era dividido com a dinâmica digital de postagens e narrativas descentralizadas nas telas de smartphones.

A suspensão do tempo do cotidiano e, simbolicamente, do tempo histórico ao longo da Copa do Mundo é um período que revigora a representação unificadora da seleção como identidade nacional, mas isso não significa "que tais eventos sejam imunes às conjunturas históricas nas quais se realizam, o que se evidencia, em especial, nas discussões sobre as derrotas brasileiras” (GUEDES, 2002, p. 2). No ano anterior ao Mundial de 2014, que foi sediado no Brasil, manifestações populares espalhadas pelo país ficaram conhecidas como Jornadas de Junho, apresentando reivindicações políticas, mas também críticas à candidatura do país como anfitrião do campeonato mundial.

Nesse sentido, o/a torcedor/a incorpora, à experiência do futebol, o smartphone como instrumento para expandi-la e ressignificá-la, via ambientes online - seja em conteúdos digitais articulados ao acompanhamento da partida, seja na manutenção do sistema

3 Lançado em 2004, o Facebook, hoje a mídia social mais acessada do mundo, atingiu a marca de dois bilhões de usuários em meados de 2017. Outras redes mundiais campeãs de audiência, WhatsApp e Instagram foram compradas pelo Facebook, em 2014 e 2012 , respectivamente. Com aproximadamente 1,7 bilhão de usuários ativos registrados em 2017, o WhatsApp é o aplicativo de mensagens mais usado no Brasil, acessado por 91\% dos internautas brasileiros, contabiliza o instituto de pesquisa online Conecta. Disponível em: http://conecta-i.com/?q=pt-br/whatsapp-\%C3\%A9-o-app-de-rede-social-mais-usado-pelos-internautas-brasileiros. Acesso em: 10 maio 2019. 
simbólico-interacional do futebol pelas redes sociais, como fazem os "peladeiros” do grupo de WhatsApp investigado.

\section{Netnografia: notas teórico-metodológicas}

O potencial da etnografia para a comunicação digital reside na centralidade do/a pesquisador/a como a principal fonte de dados através de sua experiência dentro do grupo e pressupõe uma longa imersão naquele ambiente. O objeto da etnografia é a estratificação hierárquica de estruturas significantes e a análise exige optar entre as diferentes "estruturas de significação” (GEERTZ, 1978, p. 19) e caracterizar sua importância e base social. As estruturas conceituais são múltiplas, complexas, sobrepostas, interligadas, irregulares, que precisam ser apreendidas e descritas. A experiência pessoal da etnografia tem, como um de seus objetivos, contribuir para o alargamento do universo do discurso humano, que implica em aprofundamento teórico e impregnação dos dados de campo, buscando, através da inspeção dos acontecimentos no grupo e seus sistemas de símbolos, a compreensão de sua “lógica informal, que articula as formas culturais” (GEERTZ, 1978, p. 27).

A netnografia descreve um desafio metodológico: preservar os detalhes ricos da observação em campo etnográfico usando o meio eletrônico para "seguir os atores." A experiência da efetiva participação no ambiente pesquisado inclui participar, observar e descrever categorias que formam a unidade do fazer etnográfico (BRAGA, 2012).

Uma característica que merece nota diz respeito à articulação da Internet com outras mídias que a precedem. Um ponto fundamental na caracterização dos espaços sociais disponibilizados pela Internet consiste na subordinação da atividade online a ações localmente situadas, à ordem da interação. Assim, as interações ocorrentes nas redes sociais dispersam-se por várias estruturas deste meio e estendem-se para ambientes que ultrapassam os limites digitais, em uma dinâmica interacional na qual diferentes meios são empregados de modo complementar, a serviço da comunicação entre os/as interagentes, a configurar uma “complementaridade das mídias” (BRAGA, 2008). Além disso, as atividades online estão inseridas em condições práticas de uso, utilizando-se de recursos de outros contextos comunicacionais em combinações específicas de acordo com a demanda do caso em questão. O ambiente da Internet é um local de encontro, entre outros. Participantes muitas vezes estabelecem relações para além do ambiente digital da web e utilizam vários recursos técnicos de comunicação. Ao longo das interações no WhatsApp, se fazem referências ao uso de e-mail, Facebook, Youtube, Instagram, além dos encontros presenciais. Cada uma dessas mídias é acionada para atender a diferentes demandas geradas pela situação, como privacidade, agilidade, coletividade, sociabilidade e legitimidade (BRAGA, 2008).

Na Internet, é possível verificar recorrentemente a formação de um circuito de comunicação que inclui reunião e dispersão de participantes nos vários ambientes digitais, com intensa troca de links e arquivos de texto, som e imagem, a utilização de meios complementares que supera as fronteiras digitais em encontros presenciais. A configuração 
FUTEBOL, GÊNERO E HOMOSSOCIABILIDADE NAS REDES SOCIAIS:

A MASCULINIDADE NO CIRCUITO COMUNICACIONAL DO WHATSAPP

deste circuito foi denominada em trabalhos anteriores como "circuito-comunicacional" (BRAGA, 2008).

O grupo de WhatsApp observado foi criado há três anos, visando à organização de duas peladas semanais jogadas há 18 anos nas quadras de um condomínio carioca de classe alta. Um dos autores deste artigo é membro do grupo de "peladeiros”, que reúne aproximadamente 30 integrantes, todos do sexo masculino. A condição de membro, jogador das “peladas” semanais há décadas, forneceu um pertencimento que viabilizou o estudo netnográfico realizado a partir da autorização do administrador e participantes do grupo de WhatsApp, além de longo período de tempo em campo. O grupo de WhatsApp tem o mesmo nome do condomínio que acolhe os encontros semanais, evidenciando que a identificação dos participantes do grupo é mais significativa com o status social do condomínio do que com a prática esportiva que os reúne, mesmo que a grande maioria deles não seja proprietário de um apartamento nem resida no local. Com idades entre 25 e 65 anos, estes homens partilham não só a agenda esportiva lúdica, mas também o gosto pelo futebol e sua cultura específica. A observação participante ocorreu nos ambientes de quadra, durante os jogos semanais, bem como no ambiente digital, a partir das interações ocorrentes através de trocas de memes, mensagens em texto, vídeo e áudio no período de três meses, entre abril e junho de 2018. Os nomes dos "peladeiros”, do condomínio e do grupo de WhatsApp foram omitidos, buscando preservar as identidades dos membros.

Cada objeto de pesquisa exige um dispositivo metodológico específico. Neste trabalho, foram considerados pontos dinâmicos da interação realizada, junto com dados complementares, como: i) um conjunto de postagens e comentários veiculados no grupo de WhatsApp e ii) trabalho de campo, observação participante durante as “peladas” semanais promovidas pelos participantes.

\section{Sociabilidade e futebol no WhatsApp}

A partir da noção de sociação, definida como o modo pelo qual os indivíduos se aproximam em núcleos de satisfação de seus interesses, Simmel (1983) considera que o conteúdo de uma sociação é o que está presente nos indivíduos, como impulso, interesse, estado psíquico, movimento que visa mediar influências sobre os outros. A partir de seus propósitos e das condições práticas, os indivíduos trabalham sua criatividade e sentimentos sobre os materiais da vida, conformando-os como elementos de usos específicos da vida de cada um. Entretanto, tais formas, autonomizadas, independentes de seus conteúdos originais, adquirem fascínio exatamente por esta desvinculação.

A sociabilidade é definida por Simmel (1983) como uma forma de sociação autônoma, estética e lúdica. Os fenômenos reunidos na categoria de jogo parecem funcionar de forma similar. As necessidades, impulsos e forças reais produzem formas de comportamento adequadas ao jogo, formas puras que se autonomizam e que fornecem ao próprio jogo seu 
sentido simbólico, distinguindo-o assim da simples brincadeira ${ }^{4}$. A sociabilidade evita atritos com a realidade, de modo que os motivos da sociação, implicados na vida prática, não têm importância neste contexto interacional. Para Goffman (1998, p. 19), a maior parte da interação social cotidiana é possibilitada pelo engajamento comum e voluntário dos/as participantes no que ele chama de "consenso operacional”, uma espécie de concordância superficial, onde cada participante abre mão de suas posições pessoais em prol de uma definição da situação compartilhada por todos.

Os participantes renunciam às “qualificações objetivas de sua personalidade”. Mas, se um participante interage visando propósitos objetivos, um "limiar da sociabilidade" (SIMMEL, 1983, p. 171) é transposto, desfazendo o princípio formativo do grupo, como os exemplos adiante evidenciam. De modo geral, entretanto, é possível observar no grupo uma disposição tolerante por parte dos participantes, amabilidade que poderia ser entendida como reguladora dos limiares da sociabilidade estabelecida.

Passamos a seguir à caracterização mais geral da cultura estabelecida pelos membros do grupo na quadra e no WhatsApp, seguida pela análise do corpus oriundo do ambiente digital, dados analisados a partir da técnica netnográfica, onde a própria experiência do pesquisador é fonte de dados, como descrito acima.

Nos ambientes da pelada semanal, bem como no grupo na rede social, são comuns as provocações recíprocas, tematizadas a partir de seus vínculos afetivos a clubes cariocas antagônicos. As trocas diárias entre os “peladeiros” no WhatsApp apontam para a expansão da cultura do futebol como proeminente ambiente de expressão de estereótipos de uma masculinidade culturalmente associada a status social e poder hegemônicos. Coerente, portanto, com o grande volume de conteúdos desta natureza, frequentemente superior até ao dos relacionados estritamente a futebol. Assim, a expressão de estereótipos de masculinidade observados nas trocas do grupo de WhatsApp em estudo parece se aproximar da noção de Connell e Messerschmidt (2013), que trabalham a masculinidade hegemônica como uma posição estratégica obtida através de práticas discursivas:

deveríamos compreender as normas hegemônicas como definindo posições de sujeito no discurso que é levado a cabo estrategicamente por homens em circunstâncias particulares. A masculinidade hegemônica tem múltiplos significados (...). Os homens podem se esquivar dentre múltiplos significados de acordo com suas necessidades interacionais. Os homens podem adotar a masculinidade hegemônica quando é desejável, mas os mesmos homens podem se distanciar estrategicamente da masculinidade hegemônica em outros momentos. Consequentemente, a “masculinidade” representa não um tipo determinado de homem, mas, em vez disso, uma forma como os homens se posicionam através de práticas discursivas (CONNELL; MESSERSCHMIDT, 2013, p. 257).

4 Para uma abordagem mais aprofundada sobre a noção de jogo, ver Huizinga (1971). 
Assim, no ambiente do WhatsApp, os participantes, geralmente em tom de zombaria, reafirmam e reforçam o modelo de masculinidade naturalizado na cultura do futebol. Mesmo de variadas gerações, os participantes do grupo parecem reproduzir a cultura tradicional do futebol de expressar identidades masculinas hegemônicas.

Os participantes utilizam o grupo de WhatsApp para combinar os encontros esportivos e as "resenhas" subsequentes. Os fatos, conversas e comentários transcorridos durante a "pelada” ganham ampla expressão no ambiente online na forma de memes, fotos e provocações lúdicas etc. Uma convergência e sobreposição interacional caracterizada pela complementaridade das mídias (BRAGA, 2008), como tratado acima e convergente às singulares relações jocosas futebolísticas (GASTALDO, 2010).

$\mathrm{O}$ uso que os/as participantes fazem deste ambiente afirma claramente os limites entre o que é íntimo e pessoal e que pode ser publicado. Pode-se perceber que tópicos realmente íntimos são tratados no WhatsApp, tomado pelos participantes como um lugar, sem dúvida, privado. A atividade social no WhatsApp forma um circuito de interação online entre os participantes. Durante a participação nos encontros presenciais promovidos pelos participantes, as "peladas" semanais, observa-se que muitos dos temas tratados dizem respeito à atividade online estabelecida durante a semana. Complementarmente, os encontros presenciais são descritos e discutidos no WhatsApp e as fotos tiradas são disponibilizadas posteriormente no grupo.

É interessante notar que a maior parte das postagens veiculadas compõe-se não de material produzido pelos próprios participantes, mas de memes, fotos e vídeos que circulam em outros grupos ou perfis, que, a partir de processos de seleção de quem posta, são repassados para o grupo em estudo. Muitas dessas repostagens são acompanhadas de um pequeno comentário escrito por participante do grupo, de modo a personalizar e adequar o repost para o contexto do grupo dos "peladeiros”.

Todas as imagens apresentadas neste artigo fazem parte do corpus de trabalho, composto pelas postagens veiculadas no grupo de WhatsApp “peladeiros” entre os meses de abril e junho de 2018.

O conjunto dos dados permitiu identificar alguns padrões temáticos na interação estabelecida entre os participantes do grupo de WhatsApp, todos jogadores da "pelada" semanal e torcedores dos times de futebol carioca. Tais padrões permitiram a estipulação de três categorias analíticas, denominadas:

a. Homossociabilidade masculina - o estar entre pares, o padrão mais significativo do material, indicando a mediação preferencial da interação estabelecida naquele ambiente;

b. Jocosidade de gênero, que se desdobra em três modalidades, denominadas (b.1) 'Cerveja e futebol - os homens, os jogos e o álcool'; (b.2) 'Mulheres - mães, esposas e as outras’, e (b.3) 'Proibido viadagem - ‘futebol é pra homem”;

c. Sátiras políticas - status social e poder hegemônicos. 
A seguir, detalharemos cada uma dessas categorias.

\section{Homossociabilidade masculina: o estar entre pares}

O traço preponderante da interação estabelecida pelo grupo, a exemplo de outros meios digitais, é a sociabilidade pela qual os protocolos do circuito comunicacional do grupo no WhatsApp seguem, principalmente, o padrão dos discursos elogiosos como elementochave das dinâmicas de acolhimento, reconhecimento e pertencimento em ambientes de Internet. A reciprocidade na comunicação digital é um padrão já observado em pesquisas anteriores (BRAGA, 2008), mas, aqui, tem a jocosidade como característica específica, seguindo o padrão das dinâmicas comunicativas presenciais com o tema do futebol, situação a que Gastaldo (2010) denomina "relações jocosas futebolísticas”.

A interação presencial do grupo se caracteriza como “resenha”, termo êmico, gíria utilizada para definir um intervalo de tempo de conversa amena, jocosa, sem objetivos específicos entre pares, mas pelo simples prazer de estarem juntos. Este tipo de interação, típica da sociabilidade, foi definido por um participante, em situação de campo, como "ficar relax com os brother". Assim ilustra o exemplo abaixo:

\section{Figura 1 -}

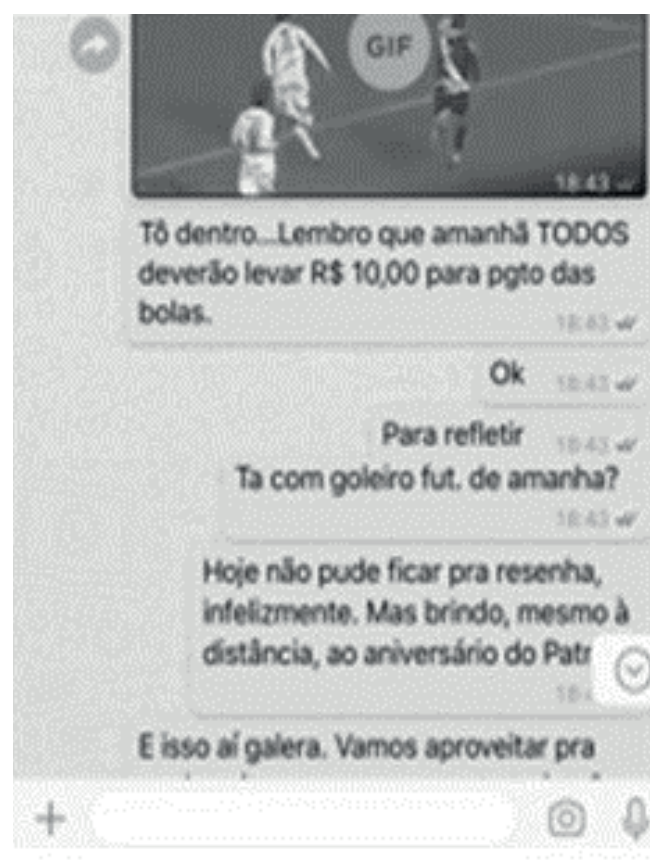

Fonte: acervo da pesquisa. 
O domínio de conteúdos que representam e reforçam um modelo masculino arraigado na sociedade ocidental contemporânea dão a tônica das publicações entre os "peladeiros", como a postagem acima demonstra. Prevalece uma anuência tácita atinente à histórica apropriação social do futebol para cristalizar valores e construções identitárias de masculinidade.

No ambiente digital, parece que os participantes adeptos da zombaria do futebol garantem o reconhecimento e pertencimento no grupo. O predomínio de mensagens lúdicas é notável, sendo ligadas a provocações de fundo clubístico e a expressões de masculinidade, compondo a maior parte das temáticas que circulam no grupo. Tais temáticas reproduzem, e até ampliam, a conversa entre torcedores homens nos bares que transmitem jogos dos campeonatos brasileiros anualmente ou da Copa do Mundo, a cada quatro anos.

Eventualmente, observam-se postagens com outras temáticas, como informações de utilidade pública, associadas a saúde/qualidade de vida, segurança pública e campanhas solidárias. Sazonalmente, ocorrem saudações em efemérides e datas comemorativas, como aniversários, Natal, Páscoa, Dia das Mães, Dia dos Pais, por exemplo. Entretanto, essas mensagens são acompanhadas do tom jocoso predominante, como os dados analisados no próximo tópico evidenciam.

Alguns participantes, incomodados com o excesso de "bobagens" que circulavam no grupo, criaram outro grupo, dissidente, para circular as mensagens estritamente sobre futebol ou sobre a pelada. Deveria reunir apenas conteúdos referentes à marcação das partidas semanais. Aos poucos, todavia, este segundo grupo passou a veicular mensagens jocosas e lúdicas, que, a despeito de algumas reclamações, prevaleceram. Esta recorrência evidencia a valorização da sociabilidade entre os "peladeiros", local de expressão de masculinidade e refúgio provisório das seriedades, desigualdades e conflitos do dia a dia operada pela cultura do futebol (DA MATTA, 1982, HELAL, 1997, GUEDES, 2002).

\section{Jocosidade de gênero}

A comunicação diária intensa entre os participantes do grupo de WhatsApp se baseia na dinâmica de provocações amistosas nos encontros depois da "pelada". São impulsionadas pelo desempenho dos times nas principais competições e pelos estigmas clubísticos presentes na interação cotidiana de torcedores antagonistas. Os ambientes de homossociabilidade masculina que sucedem a peladada - das "resenhas" presenciais às interações online - parecem estender as relações jocosas típicas do futebol a discursos afirmativos de masculinidade.

Entretanto, quaisquer comportamentos considerados menos masculinos para o grupo viram mote para a zombaria. Por exemplo, é comum torcedores do Fluminense serem chamados de "tricoletes". De forma análoga, provocações associam o Botafogo a uma atitude lamuriosa (chororô) que também estaria fora do protocolo de masculinidade, evidenciado pelo dito popular "homem (que é homem) não chora". 
Outras representações de gênero comparecem nas interações. Condutas consideradas femininas frequentemente tornam-se alvo de desqualificação na forma de piadas e provocações. Embora dentro da lógica da jocosidade futebolística, tais interações se configuram em mecanismo de construção deidentidade masculina, com base na desvalorização da feminilidade (CHODOROW apud GASTALDO, 2006). Para Kimmel (1998), não somente a feminilidade é desvalorizada, mas também as masculinidades não-hegemônicas e/ou subalternas:

Enquanto o ideal hegemónico estava sendo criado, ele foi criado em um contexto de oposição a “outros” cuja masculinidade era assim problematizada e desvalorizada. O hegemónico e o subalterno surgiram em uma interação mútua, mas desigual em uma ordem social e económica dividida em gêneros (KIMMEL, 1998, p. 105).

Atribuída a um homem, adversário naquele sistema interacional, a posse (mesmo atribuída) de um elemento considerado feminino o desqualifica no ambiente masculino.

Às representações de masculinidade, somam-se velhos e novos estigmas, apropriados pela jocosidade futebolística, remontando às representações históricas e símbolos populares dos grandes clubes - potencializadores e, ao mesmo tempo, harmonizadores de rivalidades (HELAL, 1997).

Estas práticas interacionais parecem reproduzir a histórica apropriação do campo esportivo para: i) construir e resguardar a identidade masculina idealizada na sociedade contemporânea (DUNNING, 1999); ii) engendrar, por meio de dinâmicas simbólicas, estereótipos de gênero, bem como representações sociais convenientes às ideologias dominantes (DAMO, 2003, 2007); iii) reprimir, de forma lúdica e naturalizada, expressões, segundo esta lógica consideradas femininas, que ameacem uma masculinidade idealizada e a interação lúdica entre homens, uma homossociabilidade masculina (RIAL, 1998).

Entretanto, no ambiente do grupo de WhatsApp observado, a exemplo de outros ambientes de sociabilidade entre homens, tais comentários raramente são considerados ofensa pessoal, mas pertencentes à jocosidade própria da homossociabilidade masculina ligada ao futebol.

Neste tópico, apresentamos três modalidades da jocosidade de gênero relacionadas à afirmação da masculinidade, presentes nas temáticas da interação estabelecida no grupo de "peladeiros” no WhatsApp: o consumo de álcool; a relação com as mulheres; a constante afirmação da masculinidade.

\section{Cerveja e futebol: os homens, os jogos e o álcool}

A histórica apropriação do futebol opera como locus para a construção e sedimentação da identidade de gênero masculina (GASTALDO, 2006, DAMO, 2012), sistema simbólico em torno do qual são edificados valores e papeis sociais atribuídos aos homens e naturalizados 
na sociedade ocidental contemporânea como mecanismos de hegemonia masculina. Tais mecanismos, amplamente utilizados na jocosidade das relações futebolísticas, ficam evidenciados na própria constituição do grupo observado, exclusivamente masculino, e na predominância de mensagens de expressão de gênero - por meio da afirmação de uma masculinidade idealizada.

Nesse sentido, a ostentação do consumo de álcool como marcador e evidência do pertencimento de gênero masculino está presente na forma de memes, piadas e comentários que circulam com muita frequência no grupo. Permitem a estipulação de uma categoria analítica, como os exemplos abaixo ilustram.

\section{Figura 2}

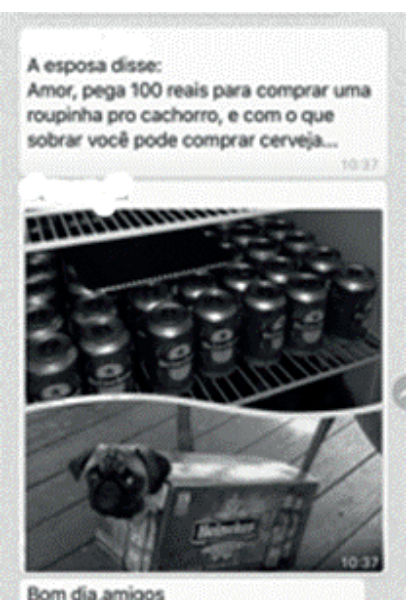

Fonte: acervo da pesquisa.

\section{Figura 4 -}

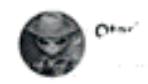

Assistindo os jogos da manhă durante a Copa do Mundo

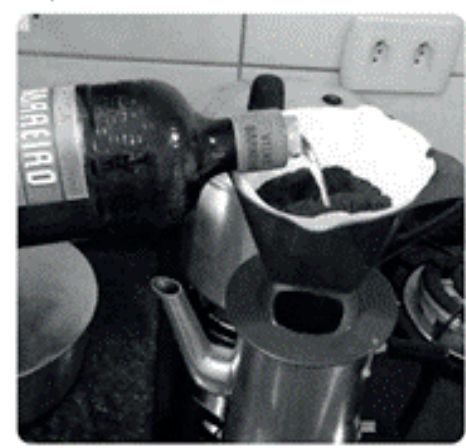

Fonte: acervo da pesquisa.

\section{Figura 3 -}

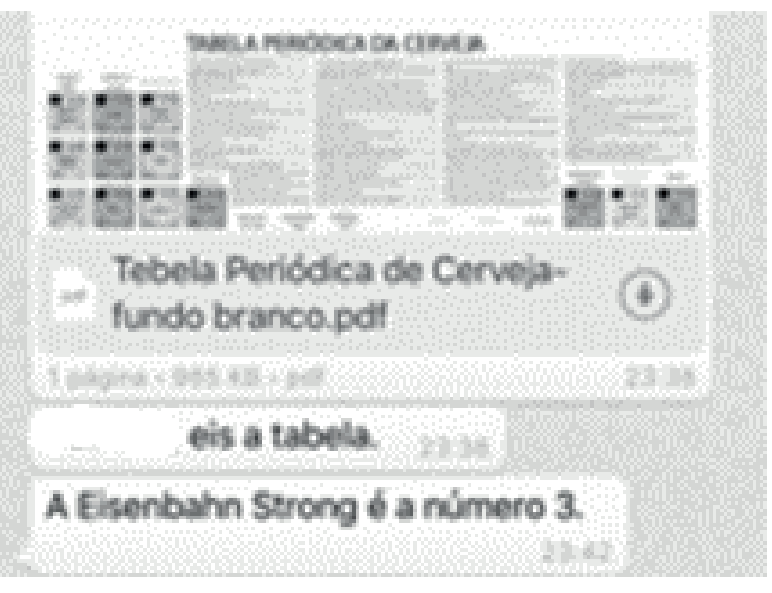

Fonte: acervo da pesquisa.

\section{Figura 5 -}

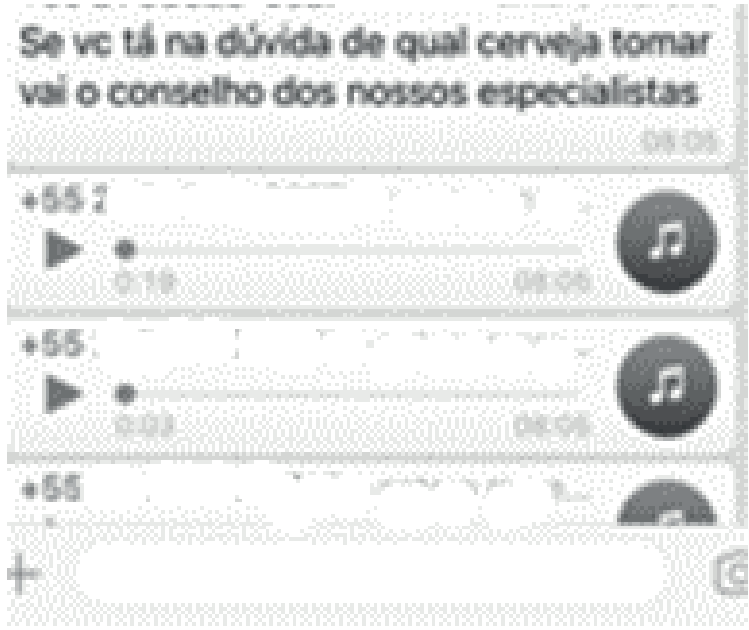

Fonte: acervo da pesquisa. 
Figura 6 -

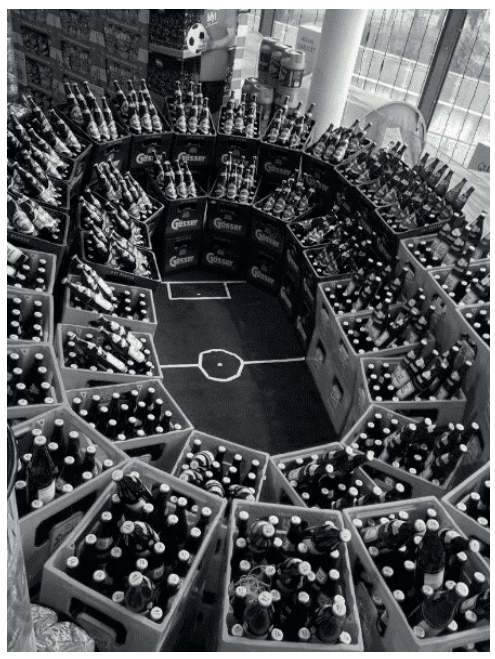

Fonte: acervo da pesquisa.
Figura 7 -

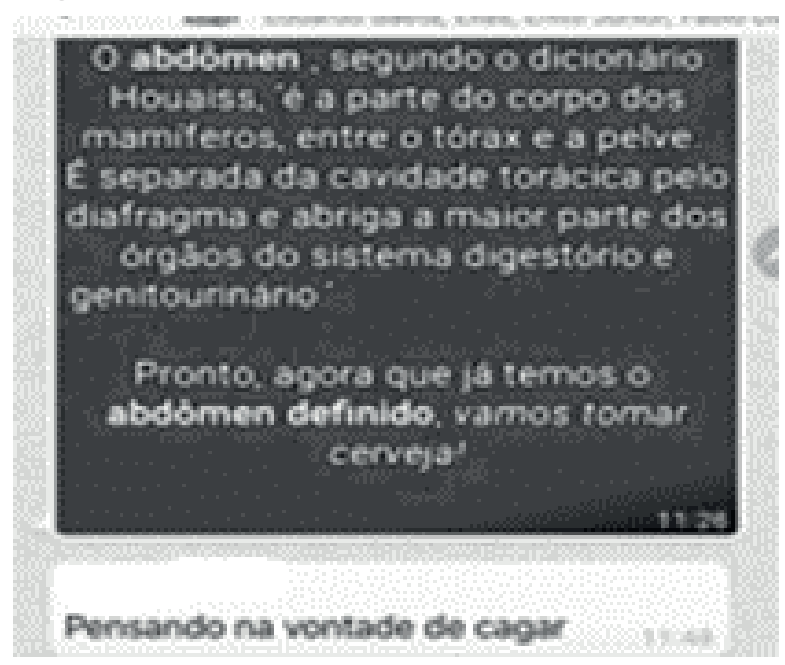

Fonte: acervo da pesquisa.

É interessante notar como o álcool ainda constitui uma parte fundamental da identidade de gênero masculina: nesse sistema, homens bebem. A disposição para o consumo excessivo de álcool como elemento inseparável da afirmação da identidade de gênero masculino no futebol fica clara na analogia da imagem da arquibancada do campo de futebol feita de engradados de cerveja (Figura 6), ou no café passado com cachaça para assistir a jogos matinais da Copa do Mundo (Figura 4). Chamam a atenção ainda a estratégia de interpretar a instrução da esposa de modo a que favoreça a compra de mais cerveja (Figura 2) e o conhecimento químico da tabela periódica aplicado ao consumo de cerveja (Figura 3). É igualmente interessante notar que recursos diversos das tecnologias de comunicação foram acionados a serviço da interação lúdica de sociabilidade e afirmação de masculinidade, como áudio, vídeo, foto e memes.

Nesse ambiente de afirmação de gênero, a escatologia (Figura 7) e a linguagem chula são elementos entendidos como apropriados para a homossociabilidade masculina, em contraste à delicadeza e elegância, entendidas e valorizadas como atributos femininos nesse ambiente de homens. Assim evidencia o vídeo intitulado por um participante "pensando na vontade de cagar”.

\section{Mulheres: mães, esposas e as outras}

Os materiais compartilhados pelo grupo apresentam um padrão recorrente de representações do modelo masculino predominante que parecem objetificar as mulheres, pois mulheres, argumenta Damo (2007), ameaçariam o tradicional uso do jogo como formador e demonstrador de uma masculinidade idealizada. 
Esses ambientes de homossociabilidade masculina conservam a tradição de tornar mulheres coadjuvantes (RIAL, 1998), assegurando domínios simbólicos de hegemonia masculina, como os exemplos abaixo ilustram.

\section{Figura 8 -}

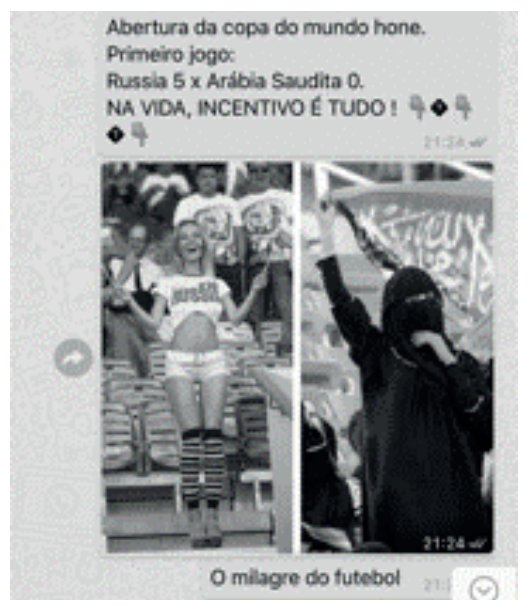

Fonte: acervo da pesquisa.

\section{Figura 10}

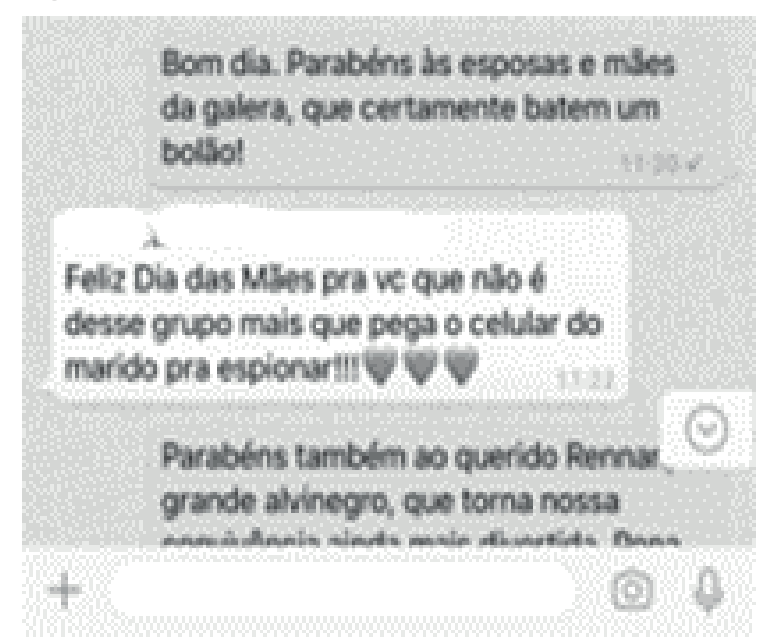

Fonte: acervo da pesquisa.

\section{Figura 9 -}

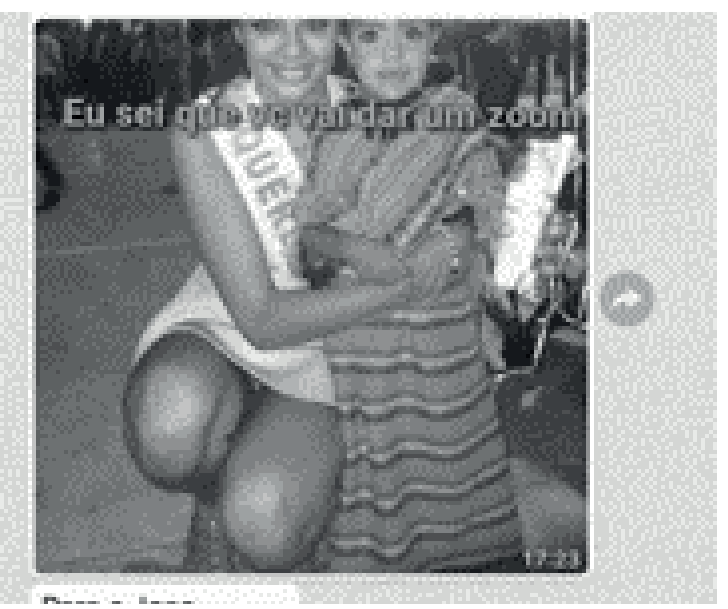

Fonte: acervo da pesquisa.

\section{Figura 11}

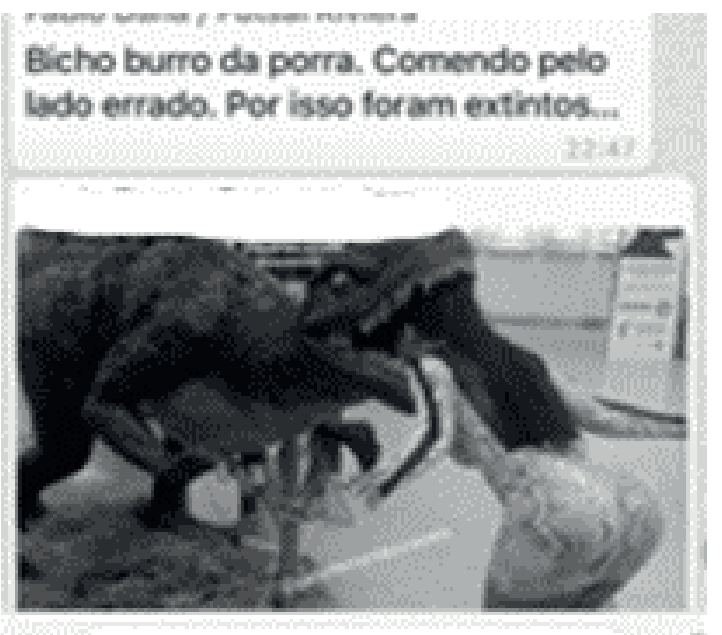

Fonte: acervo da pesquisa. 


\section{Figura 12 -}

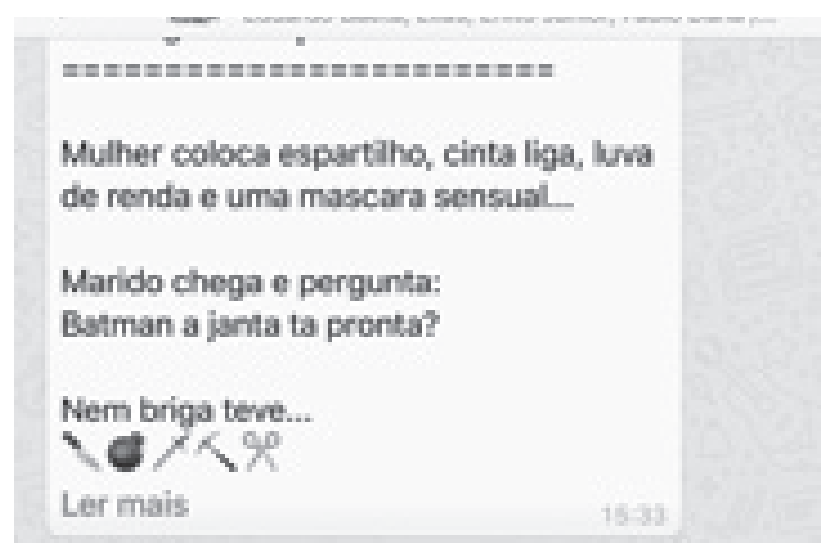

Fonte: acervo da pesquisa.

Nas postagens acima, fica clara a caracterização de três categorias distintas de mulheres: as mães, aquelas que merecem todo o respeito dos participantes; as esposas, ludicamente tratadas como intrusas na homossociabilidade estabelecida entre homens no grupo privado; e as “outras”, invariavelmente objeto de cobiça e desejo.

As mães, nesse sentido, são saudadas pelo Dia das Mães, com todo o respeito, em mensagem que utiliza a metáfora do futebol como elogio: "parabéns às mães da galera, que certamente batem um bolão” (Figura 10). Já as esposas são tratadas, em tom de brincadeira, como espiãs, ameaças à homossociabilidade masculina ali praticada. Este tratamento fica evidente na provocação, sob a forma de galhofa, endereçada às esposas dos participantes do grupo: "Feliz Dia das Mães pra vc que não é desse grupo mais (sic) que pega o celular do marido pra espionar!!!” (Figura 10). As esposas são, nesse contexto, entendidas como inconvenientes, enganadoras, ao ultrapassar territórios e papéis sociais culturalmente designados, como aprontar a "janta” na hora certa (Figura 11).

Já “as outras” - invariavelmente representadas como mulher jovem e magra - são sempre bem-vindas, entendidas como um “incentivo” (Figura 8); “os milagres do futebol”, que certamente "vc vai querer dar um zoom” (Figura 9). Além disso, não devem ser "comidas do lado errado”, a menos que seja um “bicho burro da porra” (Figura 12). Uma variação desse padrão consiste em apresentar as mulheres jovens e magras em grupo: “a mulherada”, como os dados fartamente evidenciam.

\section{Proibido viadagem: "futebol é pra homem”}

A partir do universo do futebol, segundo DaMatta (1982), pode-se compreender a sociedade brasileira, pois revela-se tanto uma dramatização das nossas tensões, contradições, 
ambiguidades e fantasias, quanto um espaço-tempo em que, como nos ritos festivos (ou dramáticos), se expressam sentimentos, identidades e papeis negligenciados em outras esferas da vida nacional ${ }^{5}$. No futebol, a masculinidade é, também, dramatizada de acordo com um modelo essencializado (RIAL, 1998, DUNNING, 1999, 1999, DAMO, 2007). Ingressar no mundo do futebol, nesse sentido, significa tornar-se parte desse "operador prático e simbólico de diversas modalidades de identidades sociais” (DAMO, 2003, p. 142), bem como dramatizar padrões naturalizados do gênero masculino.

Interessante ressaltar que quase a maioria dos integrantes do grupo tem entre 40 e 60 anos, vive em casamentos longos e estáveis, com um cotidiano comprometido com o trabalho e agendas profissionais. Entretanto, pelos discursos veiculados nas postagens acima, os participantes parecem, em geral, expressar a masculinidade por meio de discursos que ostentam, em tom predominantemente de galhofa, uma abertura ao sexo fora do casamento, o consumo exagerado de álcool e a aversão à homossexualidade, utilizada como categoria de acusação, mesmo que lúdica. Este fenômeno foi observado por Connell e Messerschmidt (2013, p. 253):

as masculinidades hegemônicas podem ser construídas de forma que não correspondam verdadeiramente à vida de nenhum homem real. Mesmo assim esses modelos expressam, em vários sentidos, ideais, fantasias e desejos muito difundidos. Eles oferecem modelos de relações com as mulheres e soluções aos problemas das relações de gênero. Ademais, eles se articulam livremente com a constituição prática das masculinidades como formas de viver as circunstâncias locais cotidianas. Na medida em que fazem isso, contribuem para a hegemonia na ordem de gênero societal.

A interação estabelecida nos circuitos comunicativos online (BRAGA, 2008) parece potencializar a jocosidade e zombaria presente na interação deste grupo, mantendo a sociabilidade como mediação principal. A ameaça mais importante à sociabilidade é a postagem de mensagens de conteúdos tidos como sérios, que possam interromper o fluxo da relação jocosa tematizada na masculinidade tão valorizada nas relações sociais entre os “peladeiros”. Nesse sentido, é interessante notar: cada vez que algum participante tenta tratar de um assunto objetivo, alguém posta, em seguida, um meme recorrente que mimetiza placa de trânsito com a figura de um veado, com os dizeres “proibido viadagem” (Figura 13). Além de "proibido" no contexto de homossociabildade do grupo, tratar de assuntos tomados como sérios pode ser entendido como "viadagem”, ameaçando, mesmo que jocosamente,

5 É importante ressaltar que, apesar da perspectiva de Da Matta (1982) representar um aporte original e pioneiro da antropologia do futebol no Brasil, seus limites interpretativos têm sido apontados por autores como Damo (2003) e Gastaldo (2014), entre outros, por reduzir o universo do futebol na cultura brasileira ao chamado "futebol-espetáculo", midiatizado, ao passo que obscurece outras práticas culturais importantes ligadas a este universo, como as "peladas” e o futebol de várzea. 
a masculinidade do participante. Neste sentido, Kimmel (1998) identifica como elementos constitutivos das masculinidades o sexismo e a homofobia:

as masculinidades são construídas simultaneamente em dois campos inter-relacionados de relações de poder - nas relações de homens com mulheres (desigualdade de gênero) e nas relações dos homens com outros homens (desigualdades baseadas em raça, etnicidade, sexualidade, idade, etc.). Assim, dois dos elementos constitutivos na construção social de masculinidades são o sexismo e a homofobia (KIMMEL, 1998, p. 105).

Nas mensagens trocadas pelo grupo são frequentes as alusões jocosas dirigidas aos outros participantes em que se insinua que são todos gays. Isso acontece tanto de modo sutil, usando flexões de gênero no feminino (“Invejosas... As duas!”, Figura 17) quanto na acusação expressa de modo direto: “São umas bichonas!” (Figura 15).

\section{Figuras 13 e 14 -}

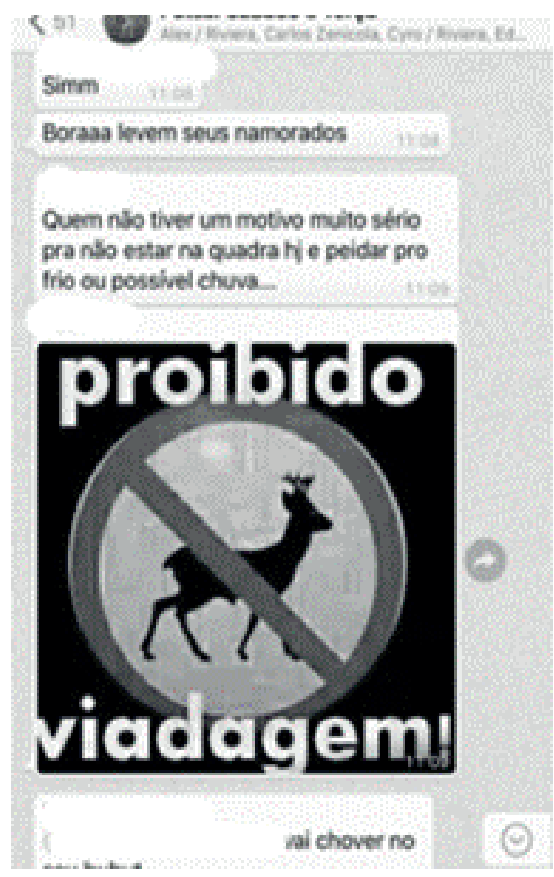

Fonte: acervo da pesquisa.

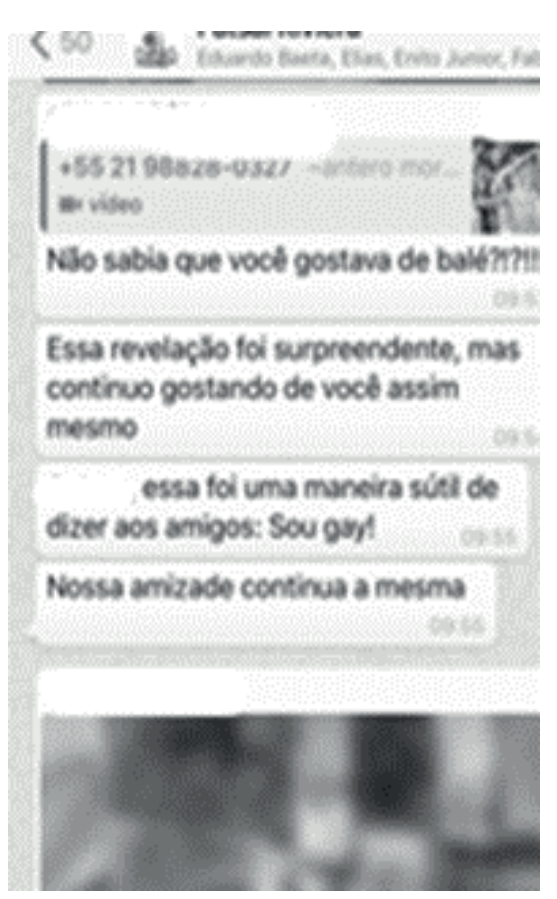

Fonte: acervo da pesquisa. 
FUTEBOL, GÊNERO E HOMOSSOCIABILIDADE NAS REDES SOCIAIS:

A MASCULINIDADE NO CIRCUITO COMUNICACIONAL DO WHATSAPP

Figuras 15 e 16 -

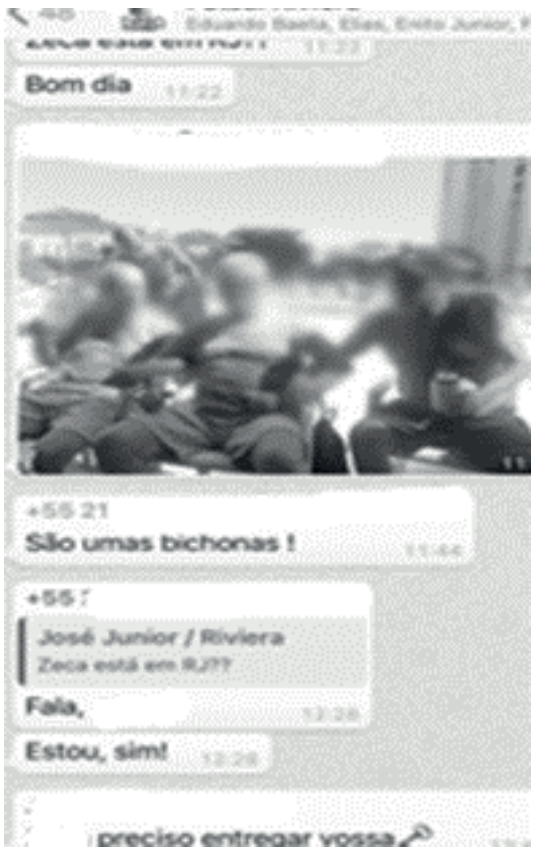

Fonte: acervo da pesquisa.

\section{Figuras 17 e 18 -}

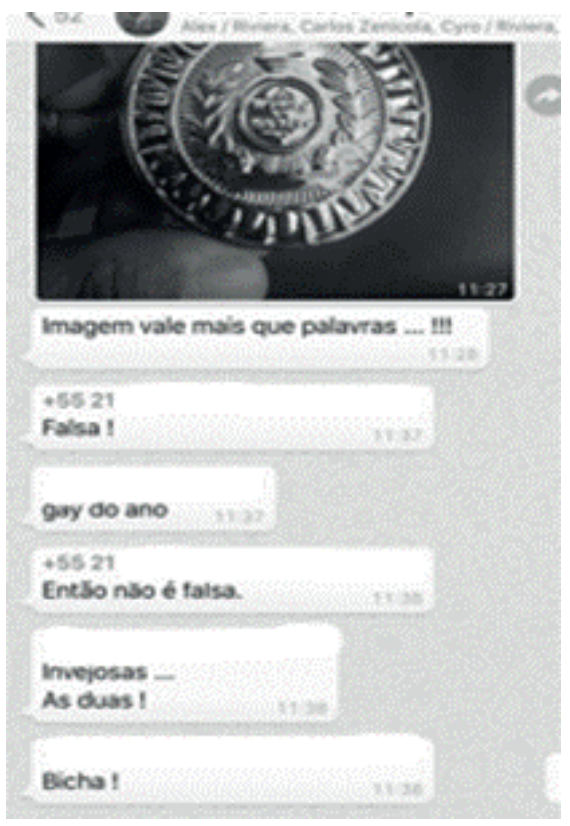

Fonte: acervo da pesquisa.

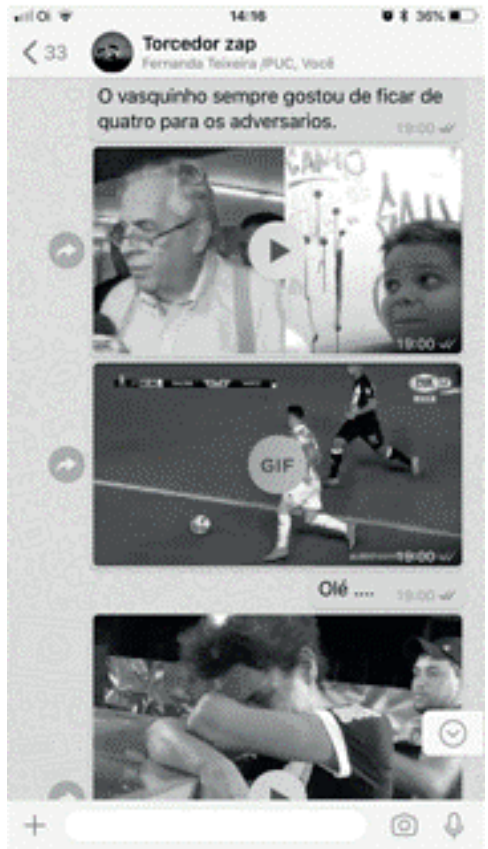

Fonte: acervo da pesquisa.

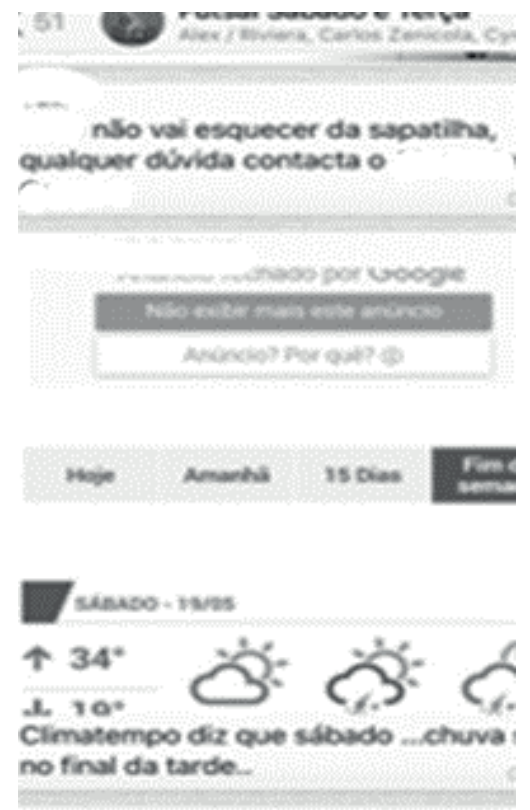

Fonte: acervo da pesquisa. 
Figura 19 -

Fonte: acervo da pesquisa.

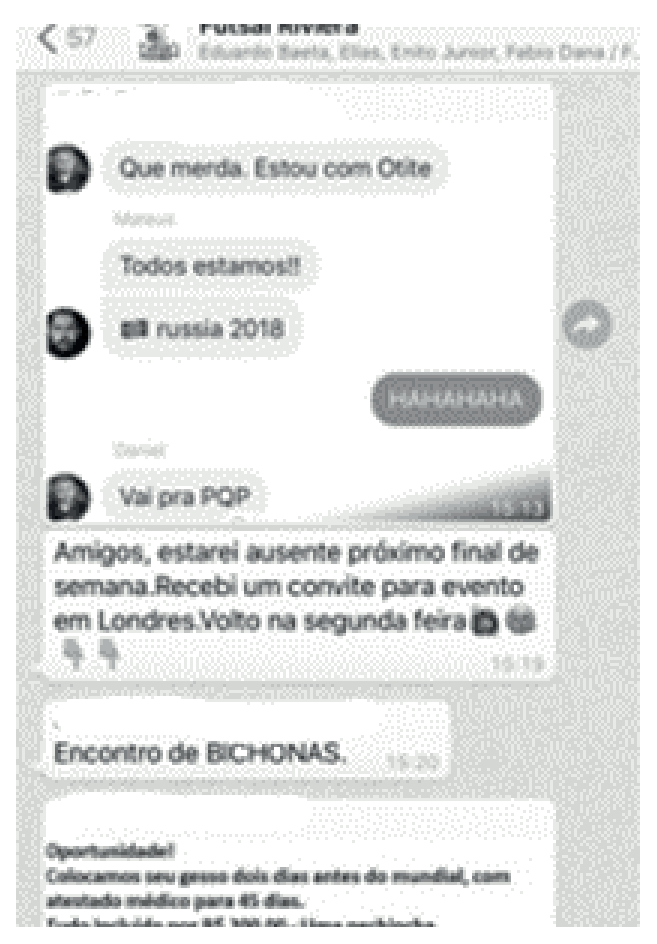

Como tratado e evidenciado pelos exemplos acima, os atributos de masculinidade valorizados no grupo estão relacionados a um suposto consumo desmedido de álcool; a certa objetificação feminina; e à afirmação/dúvida jocosa sobre a masculinidade de cada participante. Entretanto, dentro de campo, outro atributo parece sobrepor aos demais apresentados anteriormente. O jogador Neymar, durante a Copa do Mundo de 2018, ficou famoso no Brasil, bem como no mundo todo, por um comportamento um tanto dissimulado em campo, exagerando nos tombos e acidentes, ataques físicos de rivais e dores que ele fazia parecer insuportáveis. O meme abaixo com o colega de time dizendo "Neymar levanta daí, ainda está no hino Nacional!”, ironiza o comportamento do jogador favorito da seleção brasileira dentro de campo. 
Figura 20 -

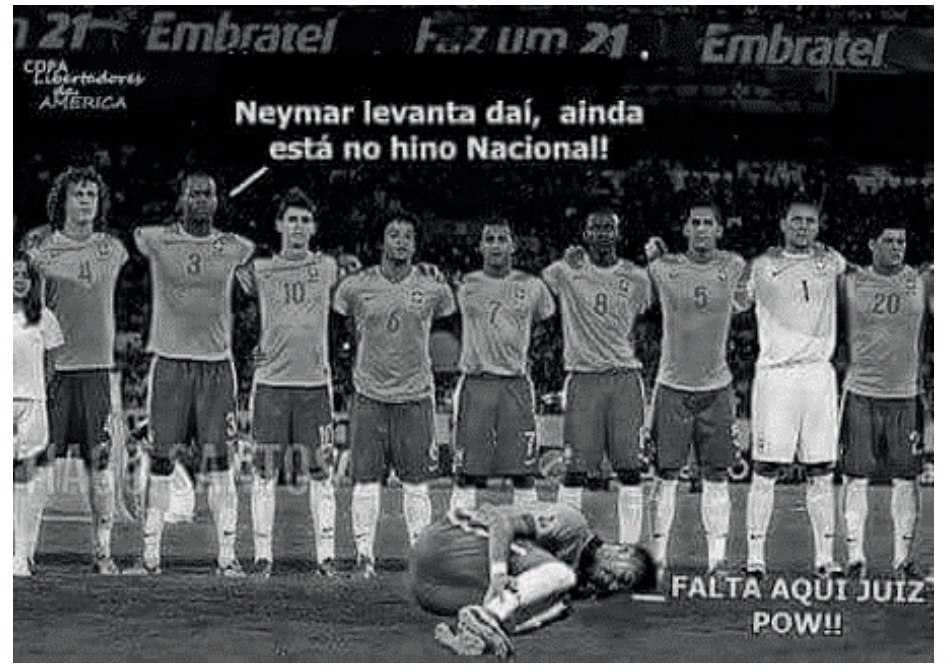

Fonte: acervo da pesquisa.

Como o exemplo acima ilustra, os vídeos e memes com Neymar Jr. circularam fartamente nas redes sociais, desmoralizando o craque com maior expectativa da torcida, na esperança da vitória do mais importante campeonato mundial de futebol. Nesse caso, mesmo a posse de atributos valorizados para a garantia indubitável de masculinidade, como a conquista de mulheres bonitas, fartos recursos econômicos e habilidade na técnica do futebol, não foi suficiente, diante de uma falta de estoicismo - atributo fundamental para a afirmação da masculinidade neste campo. "Ser homem”, nesta lógica, implica resistência diante da dor. Choramingar, "plantar" a falta, pedindo a proteção e reconhecimento do árbitro, resulta na perda de uma dimensão fundamental da masculinidade para o jogador de futebol. Como diz o dito popular "futebol é pra homem".

\section{Sátiras políticas}

Uma recorrência significativa observada no material sob análise diz respeito às mensagens de teor político que, normalmente, vinham acompanhadas do caráter lúdico da interação de sociabilidade estabelecida naquele ambiente. O cenário político do período em que os dados desta pesquisa foram coletados incluía a iminência das eleições presidenciais no Brasil, em 2018, marcada por uma polarização política sem precedentes. Após três pleitos nos quais o Partido dos Trabalhadores saiu vitorioso, ou seja, um período de 12 anos nos quais várias políticas sociais foram implementandas, essas eleições caracterizaram-se por uma participação significativa das redes sociais no processo de campanha política.

A exemplo de outros países, como Estados Unidos, Inglaterra, França e Alemanha, o posicionamento de direita angariou adeptos/as de todas as classes sociais, depois de longo 
período de avanço das questões civis ligadas à agenda política dos partidos da chamada esquerda. Neste período pré-eleitoral, foi comum a circulação de memes, fotos, piadas, vídeos e comentários de candidatos/as pelas diversas redes sociais online.

Em texto, áudio e/ou vídeo, as mensagens encaminhadas no grupo de WhatsApp observado oscilaram entre a perplexidade, a indignação, o deboche, como os dados apresentados abaixo evidenciam. Interessante notar que muitas vezes as postagens dirigiamse não ao time rival, como observado nas relações jocosas entre torcedores (GASTALDO, 2006), mas a antagonistas circunstanciais, oriundos do contexto político do país em 2018, em período pré-eleitoral. O técnico Luiz Felipe Scolari e os jogadores da seleção brasileira dividiram com os/as candidatos/as à presidência da República em período pré-eleitoral a temática dos memes ${ }^{6}$ postados nas redes sociais.

A masculinidade hegemônica se distinguiu de outras masculinidades, especialmente das masculinidades subordinadas. A masculinidade hegemônica não se assumiu normal num sentido estatístico; apenas uma minoria dos homens talvez a adote. Mas certamente ela é normativa. Ela incorpora a forma mais honrada de ser um homem, ela exige que todos os outros homens se posicionem em relação a ela e legitima ideologicamente a subordinação global das mulheres aos homens.

Homens que receberam os benefícios do patriarcado sem adotar uma versão forte da dominação masculina podem ser vistos como aqueles que adotaram uma cumplicidade masculina. Foi em relação a esse grupo, e com a complacência dentre as mulheres heterossexuais, que o conceito de hegemonia foi mais eficaz. A hegemonia não significava violência, apesar de poder ser sustentada pela força; significava ascendência alcançada através da cultura, das instituições e da persuasão (CONNELL; MESSERSCHMIDT, 2013, p. 245).

O viés político das postagens em cada grupo de WhatsApp variou conforme a posição majoritária ou exclusiva dos partipantes. No caso do grupo em questão, foram veiculados conteúdos contra os projetos sociais implementados e ataques pessoais que variaram do ódio ao deboche e sarcasmo.

6 Termo cunhado por Richard Dawkins no livro “O gene egoísta” (1976) como uma unidade de transmissão cultural, de imitação, replicada como um gene. Expressão dos ambientes digitais, o meme é construído e disseminado de maneira colaborativa, sob várias formas e com caráter predominantemente lúdico (CÂNDIDO; GOMES, 2015). 
FUTEBOL, GÊNERO E HOMOSSOCIABILIDADE NAS REDES SOCIAIS:

A MASCULINIDADE NO CIRCUITO COMUNICACIONAL DO WHATSAPP

Figuras 21 e 22 -

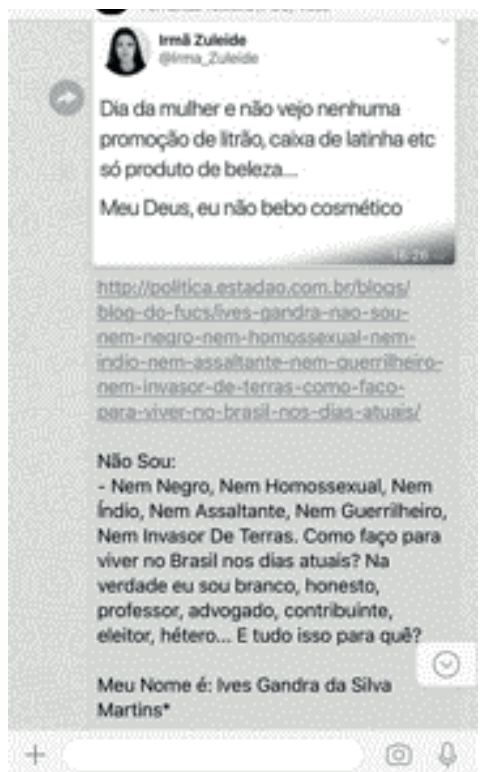

Fonte: acervo da pesquisa.

\section{Figuras 23 e 24}

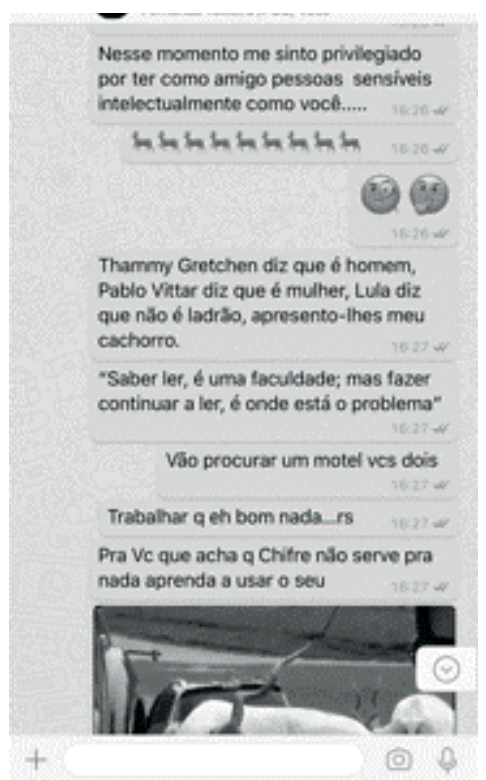

Fonte: acervo da pesquisa.

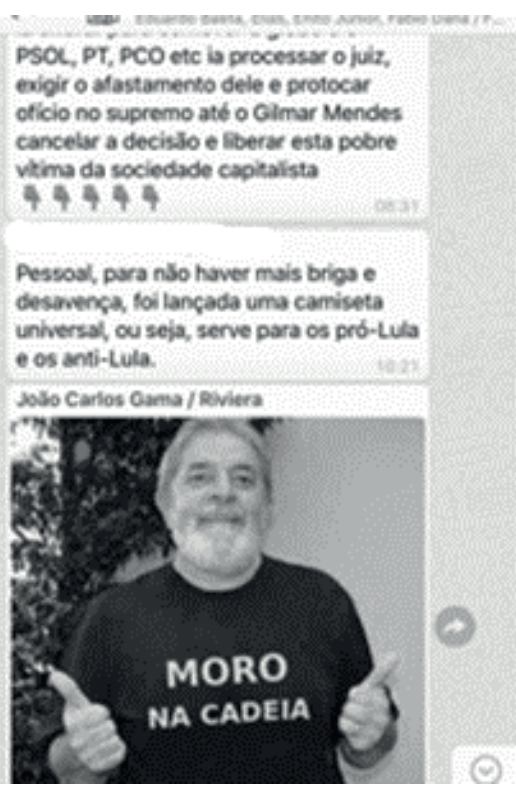

Fonte: acervo da pesquisa.

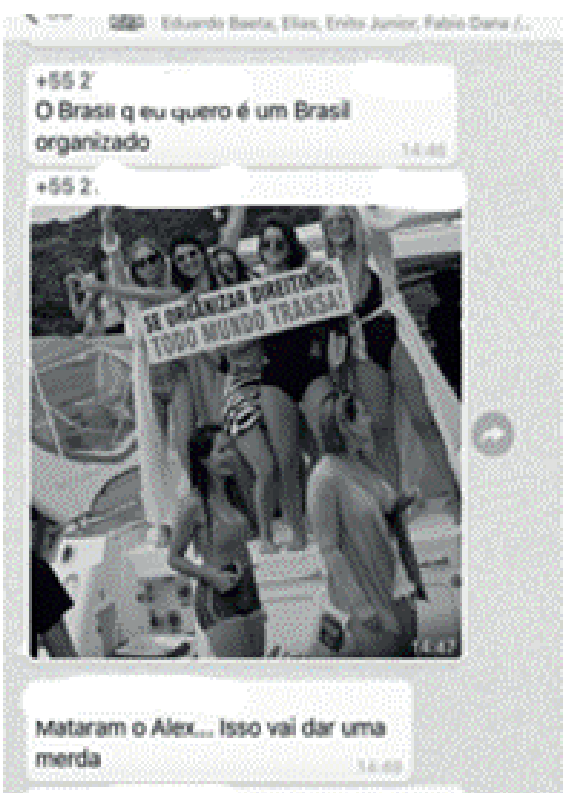

Fonte: acervo da pesquisa. 
Interessante notar que o pertencimento político observado no grupo de WhatsApp dos "peladeiros" esteve quase que invariavelmente articulado a uma posição conservadora, de direita. A postagem-desabafo repassada por um participante, que declara se sentir "agressivamente discriminado pelas autoridades governamentais constituídas” por ser “cidadão comum e branco” parece emblemática da posição do grupo. Durante um governo do Partido dos Trabalhadores, com uma mulher como Dilma Rousseff ocupando o cargo executivo máximo da nação e candidata favorita à reeleição, esta posição, preponderante entre os participantes, não chega a surpreender, considerando a classe social da qual o grupo provém e a identificação já evidenciada do grupo à elite econômica do país. Essas expressões de masculinidade hegemônica, assim, estão atravessadas por práticas e lógicas que circulam entre as classes altas de um país com profundas desigualdades sociais como o Brasil.

Em um momento de convulsão social, considerando a iminência da decisão do futuro do país no processo eleitoral que se aproximava, a postagem acima parece resumir com ironia o modelo idealizado de país que os participantes do grupo de WhatsApp sustentavam: "O Brasil que eu quero é um Brasil organizado... se organizar direitinho, todo mundo transa” (Figura 23). A postagem tira o foco da questão política e a interação fica, como nas categorias anteriores, pautada pela sociabilidade lúdica. Traço principal desta sociabilidade é a jocosidade de gênero, que toma o modelo masculino sexista como base de quase todo o seu humor e a mulher (no caso, a mulherada) é tratada como objeto sexual, sempre à disposição do entretenimento do homem "hétero branco".

\section{Conclusões}

A expressão da masculinidade essencializada como valor para fins de sociabilidade parece ter perdido lugar nos ambientes sociais contemporâneos sem que seja entendida pejorativamente como sexismo ou machismo. Assim, as redes sociais promovem ambiência para a criação de grupos fechados temáticos, redutos de homossociabilidade masculina livres do monitoramento social mais amplo.

Os processos de comunicação dos ambientes digitais estão situados no contexto sociocultural que os cerca, sendo parte de processos mais amplos de âmbito histórico, de condições sócio-históricas de produção dos discursos. As trocas interacionais acerca da masculinidade, observadas na dinâmica do circuito comunicativo do grupo de WhatsApp em análise neste estudo, tratam de uma masculinidade específica relacionada ao fenômeno do futebol no âmbito da comunicação digital.

Nestes ambientes, os recursos tecnológicos disponíveis proporcionam a formação de circuitos comunicacionais compostos de links, reposts, memes, vídeos e fotos constituídos a partir dos interesses temáticos do grupo, gerando uma sociabilidade específica e circulação 
FUTEBOL, GÊNERO E HOMOSSOCIABILIDADE NAS REDES SOCIAIS:

A MASCULINIDADE NO CIRCUITO COMUNICACIONAL DO WHATSAPP

de paródias e sátiras, conteúdos jocosos que fornecem os princípios formativos do grupo. Assim, são reproduzidas lógicas simbólicas de manutenção de uma essencialização de masculinidade idealizada, estendendo e atualizando a expressividade e as representações de gênero masculina para os ambientes digitais.

A dinâmica interacional observada no grupo de WhatsApp dos “peladeiros” evidencia a lógica simbólica que organiza a homossociabilidade masculida estabelecida pelo grupo, apoiada em uma jocosidade de gênero e numa sátira política que parecem contribuir para assegurar, simbolicamente, o status social e poder hegemônico dos seus participantes.

\section{Referências}

BRAGA, A; LOGAN, R. The Emperor of Strong AI Has No Clothes: Limits to Artificial Intelligence. Information, 2017. Disponível em: https://www.mdpi.com/2078-2489/8/4/156/htm. Acesso em: 12 dez. 2018.

BRAGA, A. Ecologia das Mídias: uma perspectiva para a comunicação. In: VIII NUPECOM - ENCONTRO DOS NÚCLEOS DE PESQUISAS EM COMUNICAÇÃO, XXXI CONGRESSO BRASILEIRO DE CIÊNCIAS DA COMUNICAÇÃO, Natal, 2008. Anais...

BRAGA, A. Sociabilidades digitais e a reconfiguração das relações sociais. Desigualdade \& Diversidade: Revista de Ciências Sociais da PUC-Rio, Rio de Janeiro, n. 9, p. 95-104, ago./dez. 2011.

BRAGA, A. McLuhan entre conceitos e aforismos. Alceu, v. 12, n. 24, p. 48-55, 2012. Disponível em: http:// revistaalceu.com.puc-rio.br/media/Artigo\%204_24.pdf. Acesso em: 12 dez. 2018.

CONNELL, R.; MESSERSCHMIDT, J. Masculinidade hegemônica: repensando o conceito. Estudos Feministas, Florianópolis, v. 21, n. 1, jan./abr. 2013.

DA MATTA, R. Esporte na sociedade: um ensaio sobre o futebol brasileiro. In: DA MATTA, R. (Org.). Universo do futebol. Rio de Janeiro: Pinakotheke, 1982.

DAMO, A. S. Paixão partilhada e participativa - o caso do futebol. História: Questões \& Debates, Curitiba, n. 57, p. 45-72, UFPR, 2012.

DAMO, A. S. A dinâmica de gênero nos jogos de futebol a partir de uma etnografia. Gênero, v. 7, n. 2, p. 137152. Niterói, UFF, 2007. Disponível em: http://www.revistagenero.uff.br/index.php/revistagenero/article/ view/148/91. Acesso em: 12 dez. 2018.

DAMO, A. S. Monopólio estético e diversidade configuracional no futebol brasileiro. Movimento, Porto Alegre, v. 9, n. 2, p. 129-156, 2003. Disponível em: http://www.ludopedio.com.br/v2/content/uploads/190912_ damo_2003.pdf. Acesso em: 10 jan. 2019.

DUNNING, E. El fenómeno deportivo: estudios sociológicos em torno al deporte, la violencia y la civilización. Barcelona: Paidotribo, 1999.

GASTALDO, E. Roberto DaMatta y el universo de la Antropología del fútbol en Brasil. Lúdicamente. Buenos Aires, v. 3, n. 6, p. 1-3, 2014.

GASTALDO, E. As Relações Jocosas Futebolísticas: futebol, sociabilidade e conflito no Brasil. Revista Mana, v. 16, n. 2. Rio de Janeiro: PPGAS/MN, 2010. 
GASTALDO, E. Futebol e sociabilidade: apontamentos sobre as relações jocosas futebolísticas. Esporte e Sociedade, n. 3, 2006.

GEERTZ, C. A Interpretação das Culturas. Rio de Janeiro, Zahar Editores, 1978.

GOFFMAN, E. A representação do eu na vida cotidiana. Petrópolis: Vozes, 1998.

GUEDES, S. O Brasil nas Copas do Mundo: o tempo “suspenso" e história. In: XXIII REUNIÃO DA ASSOCIAÇÃO BRASILEIRA DE ANTROPOLOGIA, Gramado, 2002. Anais...

HELAL, R.; SOARES, A. LOVISOLO, H. A Invenção do País do Futebol - mídia, raça e idolatria. Rio de Janeiro: Mauad, 2001.

HELAL, R. Mitos e Verdades do Futebol (que nos ajudam a entender quem somos). Insight Inteligência, n. 52, p. 68-81, 2011.

HELAL, R. Passes e impasses: futebol e cultura de massas no Brasil. Petrópolis: Vozes, 1997.

KIMMEL, M. A produção simultânea de masculinidades hegemônicas e subalternas. Horizontes Antropológicos, Porto Alegre, ano 4, n. 9, p. 103-117, out. 1998.

LOGAN, R. The Five Ages of Communication. Explorations. Media Ecology, v. 1, n. 1, p. 13-20. New Jersey: Hampton Press, 2002.

MCLUHAN, H. M. Understanding Media: The Extensions of Man. Nova York: The New American Library, 1964.

MONTAG, C.; BLASZKIEWICZ, K.; SARIYSKA, R. et al. Smartphone usage in the 21st century: who is active on WhatsApp?. BMC Research Notes, v. 8, n. 331, 2015.

POSTMAN, N. Tecnopólio: a rendição da cultura à tecnologia. São Paulo: Editora Nobel, 1994.

RIAL, C. Futebol e mídia: a retórica televisiva e suas implicações na identidade nacional, de gênero e religiosa. Antropolítica - Revista Contemporânea de Antropologia e Ciência Política. Niterói: UFF, 2003.

ROSENFELD, A.; SINA, S.; SARNE, D. A Study of WhatsApp Usage Patterns and Prediction Models without Message Content. arXIV, v. 1, 2018.

SIMMEL, G. Sociologia. São Paulo: Ática, 1983.

STRATE, L.; BRAGA, A.; LEVINSON, P. Introdução à Ecologia das Mídias. Rio de Janeiro: Edições Loyola/PUC-Rio, 2019.

\section{Adriana Andrade Braga}

Professora Associada no Programa de Pós-Graduação em Comunicação Social da Pontifícia Universidade Católica do Rio de Janeiro (PUC-Rio). Pesquisadora do CNPq. Doutora em Ciências da Comunicação na Unisinos/RS. Diretora Executiva do Media Ecology Association - MEA/ EUA. Autora dos livros “Introdução à Ecologia das Mídias” (STRATE; BRAGA; LEVINSON, Ed. Loyola, 2019), "Corpo-Verão: jornalismo e discurso na imprensa feminina” (PUC-Rio, 2016), "Personas Materno-Eletrônicas: feminilidade e interação no blog Mothern” (Sulina, 2008) e “CMC, Identidades e Género” (UBI, Portugal, 2005). Coordenadora do Laboratório de Mídias Digitais 
(LabMiD/PUC-Rio) e do Grupo de Pesquisa em Interações Digitais (GRID/CNPq). E-mail: adrianabraga@puc-rio.br.

\section{Alexandre Augusto Freire Carauta}

Professor do Departamento de Comunicação Social da Pontifícia Universidade Católica do Rio de Janeiro. Doutor em Comunicação Social pelo Programa de Pós-Graduação em Comunicação da Pontifícia Universidade Católica do Rio de Janeiro. Jornalista. Integrante do Laboratório de Mídias Digitais (LabMiD/PUC-Rio). E-mail: alexandre.carauta@.gmail.com.

Recebido em: 25.05.2019

Aprovado em: 23.09.2019 